\title{
Suicide in Brazil, 2004-2010: the importance of small counties
}

\author{
Letícia Marín-León, ${ }^{1}$ Helenice Bosco de Oliveira, ${ }^{1}$ \\ and Neury José Botega²
}

Suggested citation

Marín-León L, Oliveira HB, Botega NJ. Suicide in Brazil, 2004-2010: the importance of small counties. Rev Panam Salud Publica. 2012;32(5):351-9.

\begin{abstract}
Objective. To describe suicide rates by county size in the five geopolitical areas of Brazil. Methods. This was an ecological, descriptive study of suicide deaths in Brazil that occurred among the population 10 years of age and older in 2004-2010. Data were obtained from the National Mortality Information System of Brazil. Counties were defined by size as: very large (200 000+), large $(<200000-100000)$, medium $(<100000-50000)$, small $(<50000-$ $20000)$, very small $(<20000-10000$, and micro (<10 000). Age-adjusted suicide rates were calculated for all counties and for population-size groups in each geopolitical area. Rate ratio and $95 \%$ confidence interval were used to compare suicide risk between groups and the reference.

Results. The national, average suicide mortality rate was 5.7 deaths/100 000 inhabitants. Except in the North and North-East, suicide mortality rates increased from the very large (> 200000 ) to the micro counties (<10 000 population). Very high rates were scattered in the North and Mid-West among the indigenous peoples (> 30 deaths per 100 000). At highest risk were micro counties in the South (13.6 deaths per 100 000), with elderly males (60+ years, 31.4) and males 40-59 years (31.3) being the sex/age group with the highest rates.

Conclusions. To reduce suicide mortality in Brazil, public health authorities must support mental health training in small cities and multi-professional interventions among the indigenous peoples. In addition, the causes behind underreporting of suicide deaths must be resolved in several areas.
\end{abstract}

Key words Suicide; mortality; external causes; Brazil.

Brazil is known to have low suicide rates: in 2006, just 5.7 suicides per 100000 (1). However, the country's population has grown $17.8 \%$ from 1998 to 2008 , and during that time, suicide deaths have increased $33.5 \%$ (2). Epidemiological studies of the past two decades confirm

\footnotetext{
1 Department of Preventive Medicine, School of Medical Sciences, State University of Campinas, Campinas, São Paulo, Brazil. Send correspondence to Letícia Marín-León, email: leticia@fcm.unicamp, brleticia@fcm.unicamp.br

2 Department of Medical Psychology and Psychiatry, School of Medical Sciences, State University of Campinas, Campinas, São Paulo, Brazil.
}

higher suicide mortality rates among Brazil's males, elderly, indigenous, and in the southern part of the country, as well as rising rates among young males $(1,3-8)$.

The underreporting of suicide mortality is a problem to be addressed mainly when studying small populations. Hidden suicide has been reported among single-vehicle, single-occupant traffic accidents, undetermined intent accidents, unintentional poisoning, and other external causes as well as ill-defined causes of death (9-14).
Regarding data quality, the automaticcoding system for recording the underlying cause of death ensures national homogeneity. Legal dispositions demand that in the case of an external cause of death, the Death Certificate be completed by a doctor from the Institute of Legal Medicine in the county, after performing an autopsy to identify the cause(s) of the violence. In counties that lack such an institute, the judicial authority or the police nominate a doctor to act as an expert. Complementary toxicological laboratory exams are not widely available, thus un- 
derreporting might be higher in counties without these exams.

The association between suicide rates and county population size is controversial and fueled by a dearth of direct evidence and theories about the causes of suicide. In this respect, the relationship between urbanization and suicide is one of the most quoted, but findings are contradictory (15). In the United States of America, studies found no significant association between the population size of a county and its suicide rate $(16,17)$. A document by the Ministry of Health in Brazil reports suicide rates notably higher in small counties $(<50000$ inhabitants) (18). This finding calls into question the perception that high suicide rates are typical of large counties.

The objective of this study was to describe the suicide rates by the population size of each county in Brazil's five geopolitical areas during 2004-2010.

\section{METHODS}

This was an ecological descriptive study of suicide deaths that were defined by the underlying cause of death per the International Classification of Diseases, 10th Revision (ICD-10), codes X60-X84 (19).

\section{Data collection and definitions}

Data was obtained from the National Mortality Information System (SIM), a database managed by the Ministry of Health in Brazil (2). For every Brazilian county, suicide mortality rates by sex and age group were calculated using the respective average of suicide deaths in 2004-2010 and the population at least 10 years of age in 2007. The population of Brazil per the 2010 census was used as the standard population for the direct standardization of suicide rates.

Counties were grouped by population size into six categories within each of the five national geopolitical areas-the North, North-East, Mid-West, SouthEast, and South. The six categories, which had been previously defined by the Ministry of Health $(7,18)$, were: very large (200 000 or more), large (100 000 to $<200000$ ), medium (50 000 to < 100000 ), small (20000 to $<50000)$, very small (10 000 to < 20000$)$, and micro $(<10000)$.

Both suicide and population data, stratified by sex and age, were extracted from Datasus Tabnet (2), for each year of the study period. Since suicide deaths are uncommon, the average number of suicides in the 7-year period from 20042010 were used to avoid large annual fluctuations and small number artifacts for small counties. Suicide records that were missing data for age or county of residence were excluded. Quality of the cause of death was estimated by the proportion of ill-defined conditions as defined in Chapter 18 of the ICD-10 (19).

\section{Data analysis}

Suicide and other mortality variables were merged with population files using IBM SPSS Statistics software, version 11 (SPSS Inc., an IBM company, Chicago, Illinois, United States). This software was also used to define new variables: "geopolitical area" using the county code and "population size groups" using the total population. The Armitage method (20) was used to calculate the $95 \%$ Confidence Intervals $(95 \% \mathrm{CI})$ of the suicide mortality rate ratios of each group (area/population size) using as reference the 100000 to $<200000$ South-Eastern group. This group was chosen because of its population size, socioeconomic standing, and its health facilities. It is considered to be among the country's wealthiest groups and to have a risk of suicide mortality below the national level.

Other indicators used to study the suicide statistics' validity were also calculated, but just the two most important are shown: mortality rates of undetermined intent (ICD-10, Y10-Y34) and traffic accidents. Single-vehicle-single-occupant traffic accidents have been observed as causes of suicide underreporting, but since there is no such ICD-10 classification, the following were used: crash of a car with a fixed object (V47), car accident without crash (V48), crash of a truck with a fixed object (V57), and truck accident without crash (V58). Rate ratios were calculated for suicide rates and rates of undetermined intent, and suicide rates and specific traffic accidents.

Additionally, correlation analyses between age-adjusted suicide rates and proportion of male population and proportion of ill-defined causes of death were performed for each population size/area group using the Spearman Rank Correlation Coefficient. A correlation matrix between all age-specific suicide rates was performed.
Indigenous suicide deaths were verified for all counties in each geopolitical area and population size group.

Data obtained from Datasus Tabnet (2) excluded name and address to guarantee anonymity (2). Additionally, since all data used is openly available on government websites, ethical clearance was not necessary.

\section{RESULTS}

The national average suicide mortality rate in 2004-2010 was 5.74. Before describing the differences in suicide mortality among the geopolitical areas, the demographic and socioeconomic differences are presented. The North and North-East had the highest percentage of rural population (33\%); the others had around $10 \%$ or less. The North-East was found to be the poorest $52 \%$ living on half of the minimum wage of per capita household income) and the South, the richest ( $82 \%$ above the poverty line). Health data quality has improved, and in 2008 the death coverage ranged from $83 \%$ in the North to $96.7 \%$ in the SouthEast (21).

There were 62181 suicides in the study period among the population 10 years of age and older. None had missing data for sex; the $0.42 \%$ that were missing data for age or county of residence were excluded. Most of the excluded cases $(61.9 \%)$ were in the South-East.

The percentage of suicide records missing data for skin color/race $(4.5 \%)$ ranged from $23.9 \%$ in the state of Ceará to $0.4 \%$ in Distrito Federal, the nation's capital. States with highest suicide rates among indigenous peoples had low proportions of missing data on skin color/ race (Roraima 2.6\%, Amazon 2.1\%, and Mato Grosso do Sul 1.4\%).

Table 1 shows the mean suicide mortality rate stratified by geopolitical area and county population size. Among the counties with more than 1 million residents 10 years of age and older, only three state capitals-Fortaleza, Goiania, and Manaus-were among the four highest suicide mortality rates in their respective groups $(6.81,6.18$, and 5.01 deaths per 100000 , respectively).

In the South, it was observed that ageadjusted suicide rates increased from the very large to the micro counties (6.66, 7.72, 9.15, 10.37, 11.47, and 13.55 suicide deaths per 100000 inhabitants, 
TABLE 1. Age-standardized, average suicide mortality rates among the population 10 years of age and older, stratified by geopolitical area and county, and the four cities in each with the highest mortality rates, Brazil, 2004-2010

\begin{tabular}{|c|c|c|c|c|}
\hline $\begin{array}{l}\text { Area and county } \\
\text { population size }{ }^{\mathrm{a}}\end{array}$ & $\begin{array}{l}\text { Age-adjusted suicide } \\
\text { mortality rates } \\
\text { (per } 100000)\end{array}$ & $\begin{array}{l}\text { Rate } \\
\text { ratio }\end{array}$ & $95 \% \mathrm{Cl}^{\mathrm{C}}$ & $\begin{array}{l}\text { Four cities }{ }^{d} \text { with highest mortality rates } \\
\text { [total suicide deaths; mean suicide rate] }\end{array}$ \\
\hline Brazil & 5.74 & 1.17 & $1.14-1.20$ & - \\
\hline Very large & 4.26 & 0.97 & $0.94-1.00$ & Macapá [134; 6.8]; Rio Branco [117; 6.7]; Porto Velho [126; 5.7]; Manaus [498; 5.0] \\
\hline Large & 6.38 & 1.45 & $1.42-1.48$ & Boa Vista [125; 8.9]; Araguaína[60; 8.7]; Marabá [70; 6.4]; Palmas [72; 6.2] \\
\hline Medium & 4.77 & 1.09 & $1.05-1.12$ & Gurupi[45; 10.8]; Tucuruí [39; 7.9]; Parauapebas [42; 7.9]; Santana [39; 7.3] \\
\hline Small & 4.17 & 0.95 & $0.92-0.98$ & S.Gabriel Cachoeira [70; 32.0]; Tabatinga [68; 24.8]; Tarauacá [18; 11.5]; Colinas Tocantins [17; 10.90] \\
\hline North-East & 4.97 & 1.13 & $1.10-1.16$ & - \\
\hline Very large & 4.14 & 0.94 & $0.91-0.98$ & Teresina [325; 7.1]; Fortaleza [948; 6.8]; Aracaju [188)[6.2]; Caucaia [103; 6.1] \\
\hline Large & 4.77 & 1.09 & $1.05-1.12$ & Maracanaú [107; 9.4]; Mossoró [112; 8.6]; Sobral [78; 8.3]; Juazeiro do Norte [97; 7.3] \\
\hline Medium & 5.50 & 1.25 & $1.22-1.28$ & Caicó [48; 13.0]; Icó [39; 11.0]; Tianguá [40; 10.9]; Araripina [42; 10.1] \\
\hline Small & 5.34 & 1.21 & $1.18-1.25$ & Oeiras [33; 18.2]; São Benedito [38; 17.1]; Novo Oriente [20; 14.6]; Nova Russas [24; 14.3] \\
\hline Very small & 5.06 & 1.15 & $1.12-1.18$ & Jucurutu [22; 20.1]; Pio IX [17; 19.6]; Carnaubal [16; 19.3]; Quixelô [17; 19.3] \\
\hline Micro & 6.11 & 1.39 & $1.36-1.42$ & - \\
\hline Small & 8.70 & 1.78 & $1.75-1.81$ & Amambai [81; 43.3]; Mineiros [42; 15.9]; Paranaíba [32; 13.6]; Morrinhos [33; 13.6] \\
\hline Very small & 8.93 & 1.83 & $1.80-1.85$ & Coronel Sapucaia [29; 36.2]; Caarapó [30; 27.1]; Aparecida do Taboado [24; 19.2]; Rubiataba [21; 18.2] \\
\hline Micro & 9.96 & 2.04 & $2.01-2.06$ & Japorã [48; 109.6]; Paranhos [35; 57.8]; Tacuru [32; 51.5] \\
\hline South-East & 4.84 & 0.99 & $0.96-1.02$ & - \\
\hline Very large & 4.08 & 0.83 & $0.80-0.87$ & Uberaba [137; 7.8]; Montes Claros [149; 7.4]; Praia Grande [98; 6.6]; Piracicaba [144; 6.3] \\
\hline Large & 4.89 & 1.00 & $0.97-1.03$ & Patos de Mina [106; 12.4]; Botucatu [76; 10.2]; Divinópolis [123; 9.6]; Barbacena [67; 8.8] \\
\hline Medium & 5.49 & 1.12 & $1.09-1.15$ & Curvelo [50; 11.6]; Três Corações [47; 11.2]; Itaúna [56; 10.8]; São Roque [46; 10.3] \\
\hline Small & 5.98 & 1.22 & $1.19-1.25$ & Lagoa da Prata [44; 16.5]; Santo Antônio do Monte [27; 16.3]; Cláudio [24; 16.2]; Casa Branca [26; 15.3] \\
\hline Very small & 6.72 & 1.37 & $1.34-1.40$ & Itaguara [17; 24.0]; Papagaios [18; 23.6]; Guaranésia [27; 22.3]; Dores do Indaiá [19; 21.5] \\
\hline Micro & 6.40 & 1.30 & $1.28-1.34$ & - \\
\hline South & 9.31 & 1.87 & $1.84-1.90$ & - \\
\hline Very large & 6.66 & 1.34 & $1.31-1.37$ & Caxias do Sul [271; 10.6]; Pelotas [207; 9.6]; Novo Hamburgo [139; 8.9]; Santa Maria [148; 8.9] \\
\hline Large & 7.72 & 1.55 & $1.52-1.58$ & Santa Cruz do Sul [104; 13.7]; Passo Fundo [149; 13.7]; Uruguaiana [82; 10.5]; Rio Grande [109; 8.9] \\
\hline Medium & 9.15 & 1.84 & $1.81-1.87$ & Venâncio Aires [105; 23.8]; Lajeado [75; 18.1]; Concórdia [60; 14.4]; São Borja [57; 14.2] \\
\hline
\end{tabular}

${ }^{a}$ County population (10 years of age and older) size defined as: very large (200 000+), large $(<200000-100000)$, medium $(<100000-50000)$, small $(<50000-20000)$, very small $(<20000-$

$10000)$, and micro $(<10000)$.

${ }^{b}$ Between each population-size group and the rate of the reference group (South-East, Large).

${ }^{c}$ Confidence Interval.

${ }^{d}$ With $\geq 16$ deaths in the 7-year period.

respectively). This condition was less evident in the Mid-West and South-East. Among the other areas, the association of suicide rates and population size was not observed. Using as reference the large South-East group, it was observed that the suicide rate ratio in the South grew from the very large to the micro county group (1.34 to 2.72 , respectively) with no superposition of $95 \%$ CI. The very large, small, and very small groups in the North, and the very large in the North-East and South-East had smaller suicide rates than the reference group. The South-East counties smaller than the reference group showed higher rate ratios, especially the very small group $(1.37 ; 95 \% \mathrm{CI}=1.34-1.40)$.

For the whole study period, 588 suicides were among indigenous people. These were concentrated in the North, in the states of Amazon and Roraima (17.7 and $24.2 \%$ respectively), and in the MidWest in the state of Mato Grosso do Sul, with 312 suicides, representing $23.3 \%$ of state-wide suicides. In the North, counties with high rates of indigenous suicides were São Gabriel da Cachoeira and Tabatinga with 70 and 68 suicides, respectively (32.0 and 24.8/100 000 inhab- itants). In the Mid-West, all indigenous suicides were in the state of Mato Grosso do Sul: of the 140 suicides in Dourados (large county), 59 were among the indigenous; of 81 suicides in Amambai (small county), 65; of 29 suicides in Coronel Sapucaia (very small county), 24; and of 30 suicides in Caarapó (very small county), 21 were among the indigenous.

Some micro counties $(<10000)$ in the North, Mid-West, and South had higher, absolute numbers of suicide deaths than did larger counties in the same areas. Examples of this in the North area were Santa Isabel do Rio Negro, Amajari, and 
TABLE 2. Mortality rates (per 100000 ) of selected external causes and ill-defined causes of death among population 10 years of age and older, stratified by geopolitical area and county population size, Brazil 2004-2010

\begin{tabular}{|c|c|c|c|c|c|}
\hline $\begin{array}{c}\text { Area and } \\
\text { county size }\end{array}$ & Ulb rates & $\begin{array}{l}\text { Rate ratio Ul/ } \\
\text { suicide }^{\mathrm{C}}\end{array}$ & $\mathrm{TA}^{\mathrm{d}}$ rates & $\begin{array}{c}\text { Rate ratio TA/ } \\
\text { suicide }^{c}\end{array}$ & $\% \mathrm{ID}^{\mathrm{e}}$ \\
\hline North & 2.0 & 0.44 & 0.52 & 0.11 & 15.35 \\
\hline Very large & 1.5 & 0.34 & 2.02 & 0.47 & 11.18 \\
\hline Large & 3.1 & 0.48 & 0.99 & 0.16 & 10.29 \\
\hline Medium & 1.6 & 0.34 & 0.87 & 0.18 & 16.25 \\
\hline Small & 2.3 & 0.56 & 0.67 & 0.16 & 21.96 \\
\hline Very small & 2.6 & 0.73 & 1.64 & 0.45 & 23.85 \\
\hline Micro & 2.2 & 0.34 & 1.64 & 0.25 & 13.36 \\
\hline North-East & 6.9 & 1.40 & 0.64 & 0.13 & 11.96 \\
\hline Very large & 9.5 & 2.30 & 0.50 & 0.12 & 5.16 \\
\hline Large & 8.8 & 1.84 & 0.67 & 0.14 & 10.23 \\
\hline Medium & 6.3 & 1.15 & 0.88 & 0.16 & 11.17 \\
\hline Small & 5.2 & 0.98 & 0.72 & 0.13 & 15.80 \\
\hline Very small & 5.7 & 1.13 & 0.68 & 0.13 & 17.44 \\
\hline Micro & 4.6 & 0.75 & 0.59 & 0.10 & 16.95 \\
\hline Mid-West & 2.9 & 0.40 & 2.70 & 0.37 & 4.62 \\
\hline Very large & 2.5 & 0.44 & 2.60 & 0.45 & 2.33 \\
\hline Large & 2.6 & 0.36 & 2.05 & 0.28 & 4.36 \\
\hline Medium & 2.7 & 0.39 & 2.56 & 0.37 & 5.61 \\
\hline Small & 3.5 & 0.40 & 2.92 & 0.34 & 7.29 \\
\hline Very small & 3.4 & 0.38 & 3.22 & 0.36 & 6.14 \\
\hline Micro & 3.5 & 0.36 & 2.81 & 0.28 & 7.59 \\
\hline South-East & 8.7 & 1.80 & 0.80 & 0.16 & 7.89 \\
\hline Very large & 10.5 & 2.57 & 0.78 & 0.19 & 5.48 \\
\hline Large & 7.5 & 1.54 & 0.84 & 0.17 & 7.95 \\
\hline Medium & 6.7 & 1.22 & 0.70 & 0.13 & 10.38 \\
\hline Small & 6.4 & 1.08 & 0.88 & 0.15 & 11.50 \\
\hline Very small & 5.7 & 0.84 & 0.93 & 0.14 & 11.89 \\
\hline Micro & 6.4 & 1.00 & 0.76 & 0.12 & 13.81 \\
\hline South & 3.4 & 0.37 & 2.21 & 0.24 & 5.51 \\
\hline Very large & 3.0 & 0.45 & 1.62 & 0.24 & 4.65 \\
\hline Large & 3.6 & 0.47 & 1.68 & 0.22 & 4.57 \\
\hline Medium & 2.8 & 0.30 & 2.46 & 0.27 & 5.17 \\
\hline Small & 3.7 & 0.36 & 2.36 & 0.23 & 6.23 \\
\hline Very small & 3.9 & 0.34 & 2.83 & 0.25 & 6.83 \\
\hline Micro & 4.1 & 0.30 & 3.06 & 0.23 & 6.42 \\
\hline
\end{tabular}

a County population (10 years of age and older) size defined as: very large (200 000+), large $(<200000-100000)$, medium $(<100000-50000)$, small $(<50000-20000)$, very small $(<20000-10000)$, and micro $(<10000)$.

b Undetermined intent, Y10-Y34 (International Classification of Diseases, 10th edition [ICD-10]).

${ }^{c}$ Between each population-size group and the rate of the reference group (South-East, Large).

d Traffic accidents with no collision with other vehicle, V47-48 and V57-58 (ICD-10).

e Proportional mortality of ill-defined causes from all causes of death (ICD-10, Chapter 18).

Bonfim with 19, 16, and 18 suicides each, of which respectively 8,13 , and 9 were indigenous. In the Mid-West, there was the same situation and also a high number of indigenous suicides in Japorã (38 indigenous/48 suicides), Paranhos (29/35), and Tacuru (29/32), all in Mato Grosso do Sul state. In the South, in Rio Grande do Sul state, four micro counties had more than 20 suicides each (Planalto, Roca Sales, Sinimbu, and Vale do Sol).

According to the study criterion, which considered the total number of suicide deaths in 2004-2010, the following counties topped the list: São Paulo city with 3309 suicide deaths (rate $=4.93$ ); Rio de Janeiro city, 1064 (2.72); Fortaleza, 948 (6.81); Brasília, 787 (5.65); Belo Horizonte,
703 (4.73); Porto Alegre, 650 (7.22); and Curitiba, 564 (5.09). These were also the only counties that had more than 500 suicides in the study period.

In Table 2, the Mid-West and South are shown to have had the best quality of mortality data, with $4.6 \%$ and $5.5 \%$ as illdefined causes, respectively; in the very large counties of the Mid-West, the index was $2.3 \%$. The worst quality was in the North with $15.3 \%$ as ill-defined causes, ranging from $10.3 \%$ in the large counties to $23.8 \%$ in the very small.

Among the indicators of hidden suicide, the highest rates were from undetermined intention (UI), mainly in the North-East and South-East with values above the suicide mortality rates in most of the size groups in the two areas; thus, the $\mathrm{UI} /$ suicide rate ratio in these areas is greater than 1 . The rates of selected traffic accidents were second in magnitude, but their ranges were different from UI rates, with higher values observed in the Mid-West and South. None of these indicators had a consistent pattern among population size groups.

Table 3 shows that close to $48 \%$ of counties had a suicide mortality rate of $5-<15$ deaths per $100000 ; 29.5 \%$ had a low rate of $<5$ deaths per 100000 ; 9.7\% had 15-30 deaths per 100 000; and $11.1 \%$ had no suicide at all. This last category was mainly among micro and very small counties. Among the 28 counties with highest number of indigenous suicide, most had more than 15 deaths per 100000 people.

Male excess mortality was observed in all geopolitical areas and counties of all sizes (Table 4). Elderly males (60 years and more) had the highest rates of suicide in the Mid-West and South, independent of population size. In the South, males 40-59 years of age had highest suicide rates in the micro counties. Only in the North did male young adults (20-39 years) have slightly higher rates than the older adults. The highest adolescent male suicide rates were observed in large and micro Mid-Western counties (7.4 and 8.1 male suicides per 100000 males). Female suicide rates were higher among females 40-59 years of age than among elderly females in most groups.

Spearman Rank Correlation Coefficients between age-adjusted suicide and UI mortality rates were high (0.765). High coefficients were also observed between age-specific male suicide rates of all age brackets $(>0.830)$ and among females 20 years and more $(>0.900)$.

\section{DISCUSSION}

In the Mid-West and South geopolitical areas of Brazil, the age-adjusted suicide rates increase from the very large to the very small counties. In relation to other areas, this increase in suicide risk seems real because the proportion of illdefined causes and indicators of hidden suicide (Table 2) point to smaller values for South and Mid-West. Thus, underreporting is lower than in other areas.

In the South area, counties with higher suicide risk were mostly the smallest counties, and suicide mortality rates were higher among the elderly. The 
TABLE 3. Number of counties stratified by geopolitical area and size of county, ethnicity, and range of age-standardized, average suicide mortality rates (per 100 0000) among the population 10 years of age and older, Brazil, 2004-2010

\begin{tabular}{|c|c|c|c|c|c|c|c|c|c|c|}
\hline \multirow[b]{2}{*}{$\begin{array}{l}\text { Area and } \\
\text { county size }\end{array}$} & \multicolumn{4}{|c|}{ Counties with non-indigenous population } & \multicolumn{4}{|c|}{ Counties with indigenous population ${ }^{b}$} & \multirow[b]{2}{*}{$\begin{array}{l}\text { Counties with } \\
\text { zero suicide }\end{array}$} & \multirow[b]{2}{*}{$\begin{array}{c}\text { Total number } \\
\text { of counties }\end{array}$} \\
\hline & $\begin{array}{c}\quad<5 \\
\text { suicides }\end{array}$ & $\begin{array}{l}5-<15 \\
\text { suicides }\end{array}$ & $\begin{array}{l}15-30 \\
\text { suicides }\end{array}$ & $\begin{array}{c}>30 \\
\text { suicides }\end{array}$ & $\begin{array}{c}\quad<5 \\
\text { suicides }\end{array}$ & $\begin{array}{l}5-<15^{c} \\
\text { suicides }\end{array}$ & $\begin{array}{l}15-30 \\
\text { suicides }\end{array}$ & $\begin{array}{c}\quad>30 \\
\text { suicides }\end{array}$ & & \\
\hline \multicolumn{11}{|l|}{ North } \\
\hline Very large & 3 & 4 & 0 & 0 & 0 & 0 & 0 & 0 & 0 & 7 \\
\hline Large & 2 & 4 & 0 & 0 & 0 & 0 & 0 & 0 & 0 & 6 \\
\hline Medium & 15 & 10 & 0 & 0 & 0 & 0 & 0 & 0 & 0 & 25 \\
\hline Small & 56 & 23 & 0 & 0 & 3 & 0 & 1 & 1 & 8 & 92 \\
\hline Very small & 60 & 26 & 0 & 0 & 0 & 2 & 0 & 0 & 13 & 101 \\
\hline Micro & 54 & 92 & 12 & 0 & 0 & 2 & 4 & 2 & 52 & 218 \\
\hline \multicolumn{11}{|l|}{ North-East } \\
\hline Very large & 12 & 6 & 0 & 0 & 0 & 0 & 0 & 0 & 0 & 18 \\
\hline Large & 18 & 9 & 0 & 0 & 0 & 0 & 0 & 0 & 0 & 27 \\
\hline Medium & 34 & 33 & 0 & 0 & 0 & 0 & 0 & 0 & 0 & 67 \\
\hline Small & 162 & 144 & 2 & 0 & 0 & 0 & 0 & 0 & 2 & 310 \\
\hline Very small & 275 & 219 & 10 & 0 & 1 & 1 & 0 & 0 & 34 & 540 \\
\hline Micro & 226 & 353 & 76 & 6 & 1 & 0 & 0 & 0 & 170 & 832 \\
\hline \multicolumn{11}{|l|}{ Mid-West } \\
\hline Very large & 1 & 6 & 0 & 0 & 0 & 0 & 0 & 0 & 0 & 7 \\
\hline Large & 2 & 3 & 0 & 0 & 0 & $1^{c}$ & 0 & 0 & 0 & 5 \\
\hline Medium & 4 & 13 & 0 & 0 & 0 & 0 & 0 & 0 & 0 & 17 \\
\hline Small & 6 & 44 & 1 & 0 & 0 & 0 & 0 & 1 & 0 & 52 \\
\hline Very small & 14 & 68 & 6 & 0 & 0 & 0 & 1 & 1 & 0 & 90 \\
\hline Micro & 48 & 141 & 46 & 4 & 0 & 1 & 3 & 3 & 48 & 294 \\
\hline \multicolumn{11}{|l|}{ South-East } \\
\hline Very large & 40 & 13 & 0 & 0 & 0 & 0 & 0 & 0 & 0 & 53 \\
\hline Large & 31 & 25 & 0 & 0 & 0 & 0 & 0 & 0 & 0 & 56 \\
\hline Medium & 49 & 52 & 0 & 0 & 0 & 0 & 0 & 0 & 0 & 101 \\
\hline Small & 107 & 121 & 6 & 0 & 0 & 0 & 0 & 0 & 1 & 235 \\
\hline Very small & 116 & 176 & 16 & 0 & 0 & 0 & 0 & 0 & 9 & 317 \\
\hline Micro & 206 & 426 & 65 & 5 & 0 & 0 & 0 & 0 & 204 & 906 \\
\hline \multicolumn{11}{|l|}{ South } \\
\hline Very large & 2 & 16 & 0 & 0 & 0 & 0 & 0 & 0 & 0 & 18 \\
\hline Large & 1 & 20 & 0 & 0 & 0 & 0 & 0 & 0 & 0 & 21 \\
\hline Medium & 4 & 41 & 2 & 0 & 0 & 0 & 0 & 0 & 0 & 47 \\
\hline Small & 6 & 97 & 17 & 0 & 0 & 0 & 0 & 0 & 0 & 120 \\
\hline Very small & 24 & 125 & 46 & 0 & 0 & 0 & 0 & 0 & 0 & 195 \\
\hline Micro & 63 & 358 & 233 & 58 & 0 & 0 & 0 & 0 & 75 & 787 \\
\hline Brazil & 1641 & 2668 & 538 & 73 & 5 & 6 & 9 & 8 & 616 & 5564 \\
\hline
\end{tabular}

highest male adolescent suicide rate was observed in the micro Mid-Western counties.

North and Mid-West had some counties with high suicide risk among indigenous communities. Although they make up less than $1 \%$ of counties, the suicide mortality rates reveal a high degree of suffering among these peoples.

The extent to which small-county patterning indicates the impact of deprived environments on the population's mental health is unknown. The patterning seen in the Mid-West and South has been described in Finland (22) and United Kingdom (23), but studies in the United States have not found any such association $(16,17)$. Area differences in suicide mortality may reflect: (i) the aggregated risk of a concentration of people at high risk (compositional effect) and/or (ii) the influence of economic, social, and cultural aspects of an area on a population's mental health (contextual effect) (24). In Australia, despair among farmers undergoing reduced productivity of their lands has been described as tied to economic hardship that undermined masculinity and male family traditions (25).

The importance of suicide mortality in the South and in the very small counties traditionally devoted to agriculture is unquestionable. The fact that among the latter group fewer than $1 \%$ of counties had zero suicide may indicate a more homogenous condition in relation to suicide risks than in other geopolitical areas. As considered by a study conducted in rural England and Wales, suicide is not a problem related to being a farmer, but rather a general disadvantage in terms of poor help-seeking behavior, stigmatization of marital and mental health problems, and the seasonal fluctuation of employment and social activities (24).

Economic hardship related to the seasonal challenges inherent to farming may be observed in the Mid-West area, which has a high percentage of immigrants 


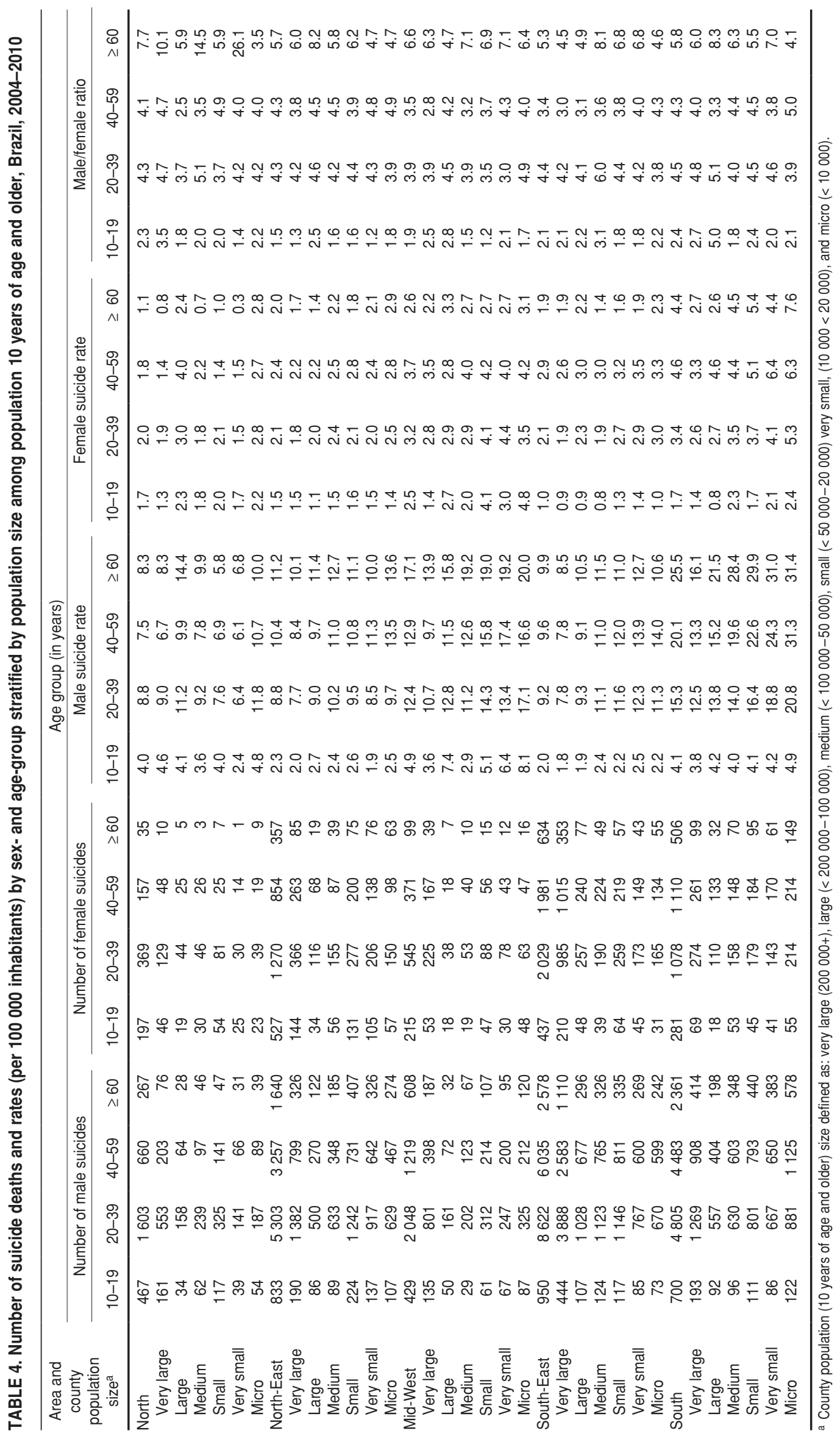


from the South. Still, in these areas, suicide as a way of ending problems might be considered a learned behavior (26). Studies such as the present one, based on secondary data, cannot point out the specific, individual risk factors related to suicide. However, it might be postulated that the smaller the county, the greater the chance of knowing someone who has committed suicide and the higher the possibility that troubled individuals might commit suicide themselves.

As observed by other studies, it is likely that farmers account for a substantial proportion of the suicide excess in some parts of the South (27-29), while indigenous communities do likewise in the North and Mid-West $(7,8,30)$. Even so, the distinction between composition and context is not straightforward in these population groups. Studies on mental health have noted a high prevalence of self-reported psychiatric symptoms and higher-than-average alcohol consumption in both groups $(31,32)$.

One factor of potential significance could be the inadequate recognition and treatment of depression and alcoholism in outlying areas, due in part to the inherent lack of health services. A study in the United States (33) observed that suicide rates were highest in counties with the smallest populations; and in rural areas, suicide was associated with lower income and fewer antidepressant prescriptions, but proportionately higher tricyclic antidepressants which, to the authors, indicated poor access to quality mental health care. The authors of the present study concur that a lack of good mental health services are an important factor to consider, and may be related to the higher suicide rates among the smaller counties in Brazil.

In the Mid-West, Mato Grosso do Sul was the state with the highest number of suicides, of which one-third were among the indigenous. Although suicide is certainly influenced by cultural and spiritual beliefs that widely differ from those of the non-indigenous population, public health policies must address the precarious health situation of the indigenous population. As observed in Queensland, Australia, rapid social changes in indigenous areas are associated with excessive alcohol use and family violence in a context of low socioeconomic status, restricted mental health care, and high suicide rates (34). In the North, in the Amazon state, the rites of passage between childhood and adulthood have been abolished, the labor opportunities are few, and young people abuse drugs and alcohol, while having low expectations for life in general (8).

Several studies have addressed underreporting of violent deaths. In São Paulo city, a study of 496 deaths, with underlying cause of death certified as "undetermined intent," found that 11 deaths were suicide, thus increasing this classification by $2.2 \%$ (35). Much of the category was homicide, but $66 \%$ of deaths of undetermined intent remained unknown, and suicide misclassification among accidental poisoning was not investigated.

A recent study observed that in the majority of Latin America, including Brazil, the number of suicide deaths was greatly outnumbered by those registered as undetermined intent (36). In the present study, this was observed in only 11 of the 30 population-size county groups, which had a rate ratio of undetermined intent/suicide of $\geq 1$, mostly concentrated in the North-East and South-East. Considering the recommendation of a previous study conducted in Europe, the rate ratio should be $\leq 0.20$ (9). This would indicate that in the present study underreporting occurred in all population size groups; however, since this rate ratio was determined in countries with very low rates of homicide, a huge problem in Brazil, its application in this population is questionable.

The strength of this study is to have calculated age-standardized suicide rates for all of Brazil's counties using a 7-year period to stabilize numerator fluctuations, thus highlighting the counties with the highest suicide rates in each area and population size. Also noteworthy is the use of a rate ratio and its $95 \% \mathrm{CI}$ to compare the magnitude of suicide risk for all of various population sizes and area groups to that of a reference group.

\section{Study limitations}

There are a number of limitations that should be considered when interpreting these findings. First, figures on suicide deaths may be underestimated. A study conducted in 2006 observed that on average, $15 \%$ of deaths occurring in
Brazil are not registered (37), and underregistration varies greatly from $3.3 \%$ in the South-East to $17.0 \%$ in the North.

Second, the undetermined intent rates and the proportional mortality from illdefined causes varied among areas and county-sizes, but compared to values in Europe were high (9).

Third, even though the smoothing procedure of average rates was applied, the study was not free of small number effects: few fatalities may have inflated the suicide rate of low-populated counties, especially those with less than 10000 inhabitants, in which figures were critical. Also, figures for very large counties may have been distorted (17) since the suicide rate is an average and these counties in Brazil are known for inequity and disparity, so a broad range in suicide risk may have been masked.

Fourth, although the larger counties have a medical examiner's office that investigates violent deaths, a high proportion of these deaths remain undetermined. In general, the larger the county, the less acquainted neighbors are with one another and the less vigilant. So, although small counties lack a medical examiner's office, neighbors are more engaged with one another and an event, such as a suicide, is unlikely to go unnoticed or be successfully covered up. Thus, part of the lower suicide mortality rates in big counties could have been due to underreporting.

Lastly, one should consider that counties in a group may differ in many traits. Employment availability, economic resources, psychiatric morbidity, healthcare access, and the ratio of the urban to rural to remote areas may differ, and are not always geographically adjacent.

\section{Conclusions}

In the Mid-West, South-East, and South areas of Brazil, suicide rates increase as size of county decreases. Although employment opportunities and economic stability are crucial, public health authorities must develop and support mental health training in small cities and multi-professional, participatory interventions among indigenous communities to effectively reduce suicide mortality in Brazil. Different causes of underreporting of suicide deaths must be addressed in several areas. 


\section{REFERENCES}

1. Minayo MCS, Pinto LW, Assis SG, Cavalcante FG, Mangas RMN. Trends in suicide mortality among Brazilian adults and elderly, 19802006. Rev Saude Publica. 2012;46(2):300-9.

2. Ministério de Saúde. Estatísticas vitais, mortalidade. Available from: http://www2. datasus. gov.br/DATASUS/index.php?area=02 Accessed on 28 July 2011.

3. Souza ER, Minayo MCS, Malaquias JV. Suicide among young people in selected Brazilian State capitals. Cad Saude Publica. 2002;18: 673-83.

4. Mello-Santos C, Bertolote JM, Wang Y. Epidemiology of suicide in Brazil (1980-2000): characterization of age and gender rates of suicide. Rev Bras Psiquiatr. 2005;27(2):131-4.

5. Brzozowski FS, Soares GB, Benedet J, Boing AF, Peres MA. Suicide time trends in Brazil from 1980 to 2005. Cad Saude Publica. 2010; 26(7):1293-302.

6. Lovisi GM, Santos AS, Legay L, Abelha L, Valencia E. Análise epidemiológica do suicídio no Brasil entre 1980 e 2006. Rev Bras Psiquiatr. 2009;31(suppl):86-93

7. Waiselfisz JJ. Mapa da Violência 2011: os jovens do Brasil. São Paulo: Instituto Sangari \& Ministério da Justiça; 2011.

8. Souza MLP, Orellana JDY. Suicide mortality in São Gabriel da Cachoeira, a predominantly indigenous Brazilian municipality. Rev Bras Psiquiatr. 2012;34:34-7.

9. Varnik P, Sisask M, Varnik A, Arensman E, Van Audenhove C, Feltz-Cornelis C, et al. Validity of suicide statistics in Europe in relation to undetermined deaths: developing the 2-20 benchmark. Injury Prevention. 2012;18(5): 321-5.

10. Gotsens M, Mari-Dell'Olmo M, RodriguezSanz M, Martos D, Espelt A, Perez G, Perez $\mathrm{K}$, et al. Validación de la causa básica de defunción en las muertes que requieren intervención medicolegal. Rev Esp Salud Publica. 2011;85:163-74.

11. Henderson AF, Joseph AP. Motor vehicle accident or driver suicide? Identifying cases of failed driver suicide in the trauma setting. Injury. 2012;43(1):18-21.

12. Pompili M, Serafini G, Innamorati $M$, Montebovi F, Palermo M, Campi S, et al. Car accidents as a method of suicide: A comprehensive overview. Forensic Sci Int. 2012;223: 1-9. Available from: http://www.science direct.com / science / article/pii/ S0379073812001776 Accessed on 20 May 2012.

13. Saman DM, Walsh S, Borowko A, Odoi A. Does place of residence affect risk of suicide? A spatial epidemiologic investigation in Kentucky from 1999 to 2008. BMC Public Health.
Available from http://www.biomedcentral. com/1471-2458/12/180 Accessed on 24 April 2012.

14. Rockett IR, Hobbs G, De Leo D, Stack S, Frost JL, Ducatman AM, Kapusta ND, Walker RL. Suicide and unintentional poisoning mortality trends in the United States, 1987-2006: two unrelated phenomena? BMC Public Health. Available from http://www.biomedcentral. com/1471-2458/10/705 Accessed on 14 October 2011.

15. Stack S. Suicide: a 15-year review of the sociological literature, part II: modernization and social integration perspective. Suic Life Threat Behavior. 2000;30(2):163-76.

16. Gove H, Hughes M. Re-examining the ecological fallacy: a study in which aggregated data are critical in investigating the pathological effects of living alone. Social Forces, 1980; 58(4):1157-77.

17. McCall P, Tittle CR. Population size and suicide in U.S. cities: a static and dynamic exploration. Suicide Life Threat Behavior. 2007; 37(5):553-64.

18. Brasil Ministério da Saúde . Saúde Brasil 2007: uma análise da situação de saúde. Brasília: Ministério da Saúde; 2008.

19. World Health Organization. International classification of diseases and related health problems, 10th revision. Available from: http:// apps.who.int/classifications/icd10/browse/ 2010/en Accessed on 18 October 2011.

20. Armitage P. Statistical methods in epidemiology. In: Statistical methods in medical research. Armitage P, Berry G, Matthews JNS, eds. Oxford: Blackwell; 1971. Pp. 426-41.

21. Brasil Ministério de Saúde. Indicadores e dados básicos, Brasil, 2010. Available from: http://tabnet.datasus.gov.br/cgi/idb2010/ matriz.htm\#demog Accessed on 12 June 2012.

22. Näyhä S. Suicide mortality in Finnish Lapnad by small areas, with reference to temporal trends. Int J Circump Health. 2009;68(3):224-34.

23. Middeton N, Whitley E, Darling D, Sterne J, Gunell D. Suicide risk in small-areas in England and Wales, 1991-1993. Soc Psychiatr Epidemiol. 2004;39(1):45-52.

24. Middleton N, Sterne JAC, Gunnell D. The geography of despair among 15-44 year-old men in England and Wales: putting suicide on the map. J Epidemiol Commun Health. 2006;60(12):1040-47.

25. Alston M. Rural male suicide in Australia. Soc Sci Med. 2012:74(4):515-22.

26. Mesoudi A. The cultural dynamics of copycat suicide. Plos One. 2009;4(9):e7252.

27. Meneghel SN, Victora CG, Faria NMX, Carvalho LA, Falk JW. Características epide- miológicas do suicídio no Rio Grande do Sul. Rev Saude Publica. 2004;38(6):804-10.

28. Viana GN, Zenkner FM, Sakae TM, Escobar BT. Prevalência de suicídio no Sul do Brasil, 2001-2005. J Bras Psiquiatr. 2008;57(1):38-43.

29. Faria NMX, Victora CG, Meneghel SN, Carvalho LA, Falk JW. Suicide rates in the State of Rio Grande do Sul, Brazil: association with socioeconomic, cultural, and agricultural factors. Cad Saude Publica. 2006;22(12): 2611-21.

30. Oliveira CS, Lotufo Neto F. Suicídio entre povos indígenas: um panorama estatístico brasileiro. Rev Psiquiatr Clin. 2003;30(1):4-10.

31. Trapé AZ, Botega NJ. Inquérito de morbidade auto-referida e exposição a agrotóxicos. In: Etges VE, Ferreira MAF, eds. A produção de tabaco: impacto no ecossistema e na saúde humana na região de Santa Cruz do Sul. Santa Cruz do Sul: Editora da UNISC; 2006. Pp. 116-41.

32. Souza MLP, Deslandes SF, Garnelo L. Modos de vida e modos de beber de jovens indígenas em um contexto de transformações. Cienc Saude Coletiva. 2010;15(3):709-16.

33. Gibbons RD, Hur K, Bhaumik DK, Mann JJ. The relationship between antidepressant medication use and rate of suicide. Arch Gen Psychiatry. 2005;62(2):165-72.

34. Qi X, Tong $\mathrm{S}, \mathrm{Hu}$ W. Spatial distribution of suicide in Queensland, Australia. BMC Psychiatr. Available from: http://www.ncbi. nlm.nih.gov/pmc/articles/PMC3006365/ Accessed on 18 October 2011.

35. Drumond Jr M, Lira MMTA, Freitas $M$, Nitrini TMV, Shibao K. Avaliação da qualidade das informações de mortalidade por acidentes não especificados e eventos com intenção indeterminada. Rev Saude Publica. 1999;33(3):273-80.

36. Pritchard C, Hean S. Suicide and undetermined deaths among youths and young adults in Latin America. Comparison with the 10 major developed countries-A source of hidden suicides? Crisis. 2008;29(3):145-53.

37. Instituto Brasileiro de Geografia e Estatística. Tábuas completas de mortalidade-2006. Available from: http://www.ibge.gov.br/home/ presidencia/noticias/noticia impressao. php?id_noticia $=1043$ Accessed on 8 February 2011.

Manuscript received on 11 November 2011. Revised version accepted for publication on 30 July 2012. 
RESUMEN Objetivo. Describir las tasas de suicidio según el tamaño del municipio en las cinco áreas geopolíticas del Brasil.

\section{Suicidios en el Brasil, 2004-2010: la importancia de los municipios pequeños}

Métodos. Estudio ecológico y descriptivo de las defunciones por suicidio en el Brasil ocurridas en la población de 10 años de edad y mayores en el período del 2004 al 2010. Se obtuvieron datos del Sistema Nacional de Información sobre Mortalidad del Brasil. Los municipios fueron definidos según su tamaño como: muy grandes (200 000 o más habitantes), grandes (de 100000 a menos de 200 000), medios (de 50000 a menos de 100 000), pequeños (de 20000 a menos de 50 000), muy pequeños (de 10000 a menos de 20000$)$ y micromunicipios (menos de 10 000). Se calcularon las tasas de suicidio ajustadas por edad para todos los municipios y según el tamaño de la población en cada área geopolítica. Se utilizaron la razón de tasas y el intervalo de confianza de 95\% para comparar el riesgo de suicidio entre los distintos grupos y el grupo de referencia. Resultados. La tasa nacional promedio de mortalidad por suicidio fue de 5,7 defunciones/100 000 habitantes. Excepto en el norte y en el noreste las tasas de mortalidad por suicidio aumentaron entre los municipios muy grandes (más de 200000 ) y los micromunicipios (menos de 10000 habitantes). Se observaron tasas muy elevadas dispersas en el norte y el centro oeste entre las personas indígenas (más de 30 defunciones por 100 000). El mayor riesgo fue observado en los micromunicipios del Sur (13,6 defunciones por 100 000), donde los varones ancianos de más de 60 años $(31,4)$ y los de 40 a 59 años $(31,3)$ fueron los grupos de edad y sexo que presentaron las tasas más elevadas.

Conclusiones. Para reducir la mortalidad por suicidio en el Brasil, las autoridades de salud pública deben abordar la capacitación en materia de salud mental en las pequeñas ciudades y promover las intervenciones interdisciplinarias en los pueblos indígenas. Además, en varias zonas se deben resolver las causas que provocan la insuficiente notificación de las defunciones por suicidio.

Palabras clave Suicidio; mortalidad; causas externas; Brasil. 